\title{
Relationship between Gymnastics Exercise and Insomnia in Elderly
}

\author{
Fauziah Nurillah Nasa, ${ }^{1}$ Sharon Gondodiputro, ${ }^{2}$ Lina Rahmiati ${ }^{2}$ \\ ${ }^{1}$ Diploma IV of Midwifery Program, Faculty of Medicine, Universitas Padjadjaran \\ ${ }^{2}$ Department of Public Health, Faculty of Medicine, Universitas Padjadjaran
}

\begin{abstract}
Objective: To analyze the relationship between gymnastics exercise and insomnia in elderly.

Methods: This study involved 60 elderly as the respondents. The respondents were divided into two groups: group 1 consisting of elderly who practiced gynmastics exercise and group 2 consisting of elderly who did not practice gymnastics exercise. The members of group 1 were enrolled from 3 gymnastic groups in 3 villages in Jatinangor, West Java, Indonesia and the members of group 2 were elderly who lived in the same villages as the elderly in group 1. The inclusion criteria were elderly women who could communicate effectively and with a Mini Mental State Examination (MMSE) score of $>23$. Particularly for group 1, additional criteria were applied, i.e. elderly who did gynmastics exercise minimal once a month and each exercise lasted for at least one hour. Insomnia level was determined using the insomnia severity index (ISI). This study was carried out in June 2017. Homogeneity of the groups was examined using proportion difference test and data were analyzed using chi-square test and one way ANOVA.
\end{abstract}

Results: Insomnia prevalence was $56.6 \%$ but insomnia prevalence in group 2 was higher $(43.3 \%)$ than that of group $1(13.3 \%)$. This study discovered that there was significant relationship between gymnastics exercise and insomnia in elderly $(\mathrm{p}=0.000)$. Referring to the frequency of the gymnastics exercise, significant relationship between gymnastics exercise and insomnia in elderly

Received: was also found $(\mathrm{p}=0.040)$.

November 10, 2017

Revised:

December 12, 2017

Conclusions: Gymnastics exercise is a promising nonpharmacologic therapy to treat insomnia in elderly.

Keywords: Elderly, insomnia, gymnastics exercise

Accepted:

February 22, 2017

pISSN: 2302-1381; eISSN: 2338-4506; http://doi.org/10.15850/ijihs.v6n1.1132
IJIHS. 2018;6(1):30-5

\section{Introduction}

Indonesia is currently facing increased number of elderly ( $>60$ years old) due to rise in life expectancy and reduction of total fertility. During the past 10 years, the life expectancy has increased from 70.9 years in 2015-2020 to 72 years in $2025-2030 .{ }^{1}$ Additionally, the percentage of elderly is increasing persistently. In 2015 , the percentage of elderly was $8.5 \%$ but this percentage is estimated to approximately $11.8 \%$ in $2025 .^{1}$

\section{Correspondence:}

Fauziah Nurillah Nasa, Diploma IV of Midwifery

Program, Faculty of Medicine, Universitas Padjadjaran

Jl. Raya Bandung-Sumedang KM 21 Jatinangor,

Indonesia

e-mail: fnurillahnasa@gmail.com
Physical or psychological health problems may occur during aging, including problems related to sleep-wake cycle. The sleep-wake cycle problem that is most commonly found in elderly is insomnia. ${ }^{2}$ Insomnia is known as a condition of difficulty to fall asleep, maintain sleep, wake up very early in the morning, or lower quality of sleep that relates to daytime activity interferences, such as tiredness and memory disturbance. ${ }^{3}$ Insomnia prevalence in elderly may vary in various countries. A previous study conducted by Kim et al. ${ }^{2}$ in South Korea found that $29.2 \%$ of citizen $>65$ years had insomnia. Another study in Egypt stated that the percentage of elderly who had insomnia was $33.6 \%$ while in Taiwan the insomnia prevalence among elderly was 
$41 \%{ }^{4,5}$ Studies on insomnia among Indonesian elderly are limited; however, a study which was conducted in Bali, Indonesia has discovered a high insomnia prevalence (40\%). ${ }^{6}$

Many factors may cause insomnia. A study by Jaussent et $a l^{7}$ reported that age, female, sleeping pill consumption, nightmare, chronic diseases, and depression are among factors that cause insomnia in elderly. Furthermore, previous studies revealed that lower education background and smoking may also becaome factors that lead to insomnia. ${ }^{8,9}$

Insomnia in elderly can be treated by using treatments that are pharmacological and nonpharmacological in nature. Good sleep hygiene, sleep restriction, cognitive behavioral method, relaxation, stimulus control therapy, as well as physical activities/exercise are among the known non-pharmacological approaches ${ }^{10}$ In elderly, physical activities do not only treat sleeping problems but also makes elderly to be more healthy. ${ }^{10-13}$ The type and intensity of exercise for elderly should be adapted to their specific condition. ${ }^{14,15}$ One of the types of exercise that is easy for elderly is gymnastics exercise. This study aimed to understand the relationship between gymnastics exercise and insomnia in elderly.

\section{Methods}

This was a cross-sectional analytical study comparing two groups, elderly group who did exercise and elderly group who did not do any exercise. The study was performed on elderly people who, at the time of the study, lived in
Jatinangor sub-district, Sumedang, West Java Province, Indonesia. The study was conducted in June 2017 and has been approved by the Health Ethics Committee, Faculty of Medicine, Universitas Padjadjaran through the issuance of ethical clearance number 577/UN6.C10/ PN/2017.

A sampling calculation method was used to determine the total number of respondents. Thirty respondents were recruited for each group. The inclusion criteria were elderly women whoseage was 60 years or above, ableto communicate effectively with comprehensive language, did not have dementia proven by a Mini Mental State Examination (MMSE) score of $>23$. An additional inclusion criterion were applied for the first group, i.e. elderly who joined gymnastics exercise class for the last month and attended exercise class for elderly minimum once a month. The exclusion criteria in this study were elderly who had chronic diseases and those who did not want to participate in the study.

In Jatinangor sub district, 3 out of 7 villages had elderly gymnastics exercise groups with a total number of members of 35 . The number of elderly who did not join gymnastics exercise group was 34 . The respondents' names and addresses were recorded through interviews done by cadres. Before the study was started, the respondents were given information on the aim of this study. The respondents who understood and agreed to participate filled and signed the informed consent. The MMSE test was then performed. If the score was $>23$, insomnia measurement were then carried out by using the Insomnia Severity Index (ISI).

Table 1 Respondents' Age and Educational Background Distribution

\begin{tabular}{lccc}
\hline \multirow{2}{*}{ Characteristics } & $\begin{array}{c}\text { Gymnastics } \\
\text { Exercise Group }\end{array}$ & $\begin{array}{c}\text { Non-Gymnastics } \\
\text { Exercise Group }\end{array}$ & Total \\
\cline { 2 - 4 } & (n) & (n) & (n) \\
\hline Age (yrs.) & 27 & 26 & 53 \\
60-69 & 3 & 4 & 7 \\
$>70$ & & & \\
Educational background & 13 & 15 & 28 \\
Primary school & 10 & 9 & 19 \\
Junior high school & 4 & 3 & 7 \\
Senior high school & 3 & 3 & 6 \\
College graduate & 30 & 30 & 60 \\
\hline \multicolumn{1}{c}{ Total } & & & \\
\hline
\end{tabular}


Table 2 Gymnastics Exercise Frequency per Month

\begin{tabular}{lc}
\hline $\begin{array}{c}\text { Gymnastics Exercise } \\
\text { Frequency }\end{array}$ & (n) \\
\hline $1 \mathrm{x}$ in a month & 6 \\
$2 \mathrm{x}$ in a month & 7 \\
$3 \mathrm{x}$ in a month & 10 \\
$4 \mathrm{x}$ in a month & 7 \\
\hline Total & 30 \\
\hline
\end{tabular}

Insomnia Severity Index is one of the most widely used distinctive test to measure sleep problems. The American Thoracic Society or ATS stated that this test contains 7 items with questions on the severity of sleep onset, sleep maintenance, and early morning awakening problems, sleep dissatisfaction, interference of sleep, difficulties with daytime functioning, noticeability of sleep problems by others, and distress caused by the sleep difficulties. ${ }^{16}$, The recall period is the "last week". A 5-point Likert scale is used to rate each item $(0=$ no problem; $4=$ very severe problem), yielding a total score that ranges from 0 to 28 . The level of insomnia is classified into the following 4 categories: absent of insomnia (0-7), sub-threshold of insomnia (8-14), moderate insomnia (15-21), and severe insomnia (22-28).

The appropriate frequency of gymnastics exercise for elderly is stated as once a week or four times a month. In this current study, the gymnastics exercise frequency was divided into the following 4 categories, once a month, twice a month, three times a month, and four times a month.

Table 3 Insomnia Level Based on Insomnia Severity Index

\begin{tabular}{lcc}
\hline \multicolumn{1}{c}{ Score } & $\begin{array}{c}\text { Gymnastics } \\
\text { Exercise } \\
\text { Group }\end{array}$ & $\begin{array}{c}\text { Non- } \\
\text { Gymnastics } \\
\text { Exercise } \\
\text { Group }\end{array}$ \\
\cline { 2 - 3 }$(\mathrm{n})$ & $(\mathrm{n})$ \\
\hline $\begin{array}{l}\text { Absent insomnia } \\
\begin{array}{l}\text { Sub threshold } \\
\text { insomnia }\end{array}\end{array}$ & 22 & 4 \\
$\begin{array}{l}\text { Moderate } \\
\text { insomnia }\end{array}$ & 6 & 15 \\
Severe insomnia & 0 & 9 \\
\hline \multicolumn{1}{c}{ Total } & 30 & 2 \\
\hline
\end{tabular}

The typical gymnastics exercise lasted 60 minutes: 15 minutes warming up, 30 minutes main course, and 15 minutes cooling down. The respondents' characteristics documented were age and educational background. Two age groups were used: 60-69 years old and $\geq 70$ years old age group. Four categories were applied for educational background: primary school, junior high school, senior high school, and college graduate. Data homogeneity for respondents' age data in both groups was analyzed by using proportion difference test. Data were then examined statistically by using chi-square test for comparative analysis of two unpaired groups and one way ANOVA for comparative analysis of more than two groups.

\section{Results}

This study included sixty respondents and discovered that the age distribution in both groups was homogeneous based on the results of two groups' proportion difference test. The majority of the respondents were in the 6069 years old age group with lower educational background (Table 1).

In the gymnastics exercise group, most of the respondents exercised three times a month with only 7 respondents exercised four times a month (Table 2).

The absent of insomnia was found in 22 respondents who did gymnastics exercise (Table 3) although 4 respondents in the nongymnastics exercise group also did not have insomnia.

Total number of respondents in gymnastics exercise and non-gymnastics exercise groups who had insomnia were 34 (Table 4). The p value significance for the chi-square test awas $0.000(<0.05)$. This showed that a relationship between gymnastics exercise and insomnia in elderly was found.

Most respondents who did exercises more than once a month presented a lower insomnia level (Table 5). Higher risk of severe insomnia was frequently found in elderly who exercised once a month. Based on the results using one way ANOVA, the $p$ value significance for this was $0.040(<0.05)$.

\section{Discussion}

Elderly may experience various health-related problems, including insomnia, which disturb daily activities. ${ }^{2}$ Insomnia prevalence in many 
Table 4 Relationship between Exercise and Insomnia in Elderly

\begin{tabular}{|c|c|c|c|c|}
\hline \multirow{3}{*}{ Exercise } & \multicolumn{2}{|c|}{ Insomnia } & \multirow{3}{*}{$\begin{array}{c}\text { Total } \\
\text { (n) }\end{array}$} & \multirow{3}{*}{$p$ value } \\
\hline & Yes (+) & No (-) & & \\
\hline & (n) & (n) & & \\
\hline Yes (+) & 8 & 22 & 30 & 0.000 \\
\hline No $(-)$ & 26 & 4 & 30 & \\
\hline Total & 34 & 26 & 60 & \\
\hline
\end{tabular}

countries varied between $20-40 \% 0^{2,4-6}$ In this study, insomnia prevalence is quite high when compared to the previous studies. This higher percentage was caused by higher percentage of elderly who did not exercise while insomnia prevalence of elderly who exercised was lower.

Based on the statement made by Widianti and Proverawati in Yurintika, the exercise for elderly is typically light and easy to perform. ${ }^{16}$ Atikah and Suarti as quoted by Manangkot added that the exercise for elderly contains a sequence of easy rhythmic motions involving all muscles and joints. ${ }^{17}$ This exercise also has recreational elements and flexible, so that it can be done both indoor and outdoor. This study discovered that there was a relationship between gymnastics exercise and insomnia. A theory that elaborates relationship between physical activities, including exercise, and sleep is the thermoregulation effect theory. ${ }^{10,11}$ This theory stated that physical activity/exercise can increase human body temperatur and stimulate body to decrease the temperature mechanically by releasing heat. Hence, blood flow to the skin increases, which can stimulate process of sleeping. ${ }^{10,11}$ Glotzbach and Heller, as stated in Varrasse and Passos, revealed that insomnia may occur due to the failure in temperature downregulation at night. . $^{10,11}$

Another theory which explains the effect of physical activity/exercise on sleep is the anxiolytic and antidepressant effect theory. ${ }^{10,11}$ Anxiety is suggested to play a major role in insomnia ${ }^{10,11}$ because one of several symptoms frequently found in insomnia is anxiety. ${ }^{10} \mathrm{~A}$ previous study has revealed that patients with chronic insomnia can decrease their anxiety before sleeping by practicing aerobic exercise with a moderate intensity. ${ }^{10}$ Another study found that there are several positive effects between aerobic exercise and sleep quality, as well as reduction of depression symptoms. ${ }^{11}$

It is believed that physical activity/exercise can improve immune functions. ${ }^{10}$ In healthy elderly men, some evidence were found to support this notion, including a decrease in awakening time, rapid eye movement (REM) latency, interleukin-6 (IL-6), tumor necrosis factor- $\alpha$ (TNF- $\alpha$ ), TNF- $\alpha /$ interleukin-10 (IL10) ratio, and increased IL-10 level. ${ }^{10}$

Different insomnia levels were found to be affected by the exercise frequency in a

Table 5 Relationship between Gymnastics Exercise for Elderly and Insomnia Based on Exercise Frequency

\begin{tabular}{|c|c|c|c|c|}
\hline \multirow{3}{*}{ Exercise for Elderly } & \multicolumn{2}{|c|}{ Insomnia } & \multirow{3}{*}{$\begin{array}{c}\text { Total } \\
\text { (n) }\end{array}$} & \multirow{3}{*}{$p$ value } \\
\hline & Yes (+) & No $(-)$ & & \\
\hline & (n) & (n) & & \\
\hline $1 \mathrm{x}$ in a month & 4 & 2 & 6 & 0.040 \\
\hline $2 x$ in a month & 1 & 6 & 7 & \\
\hline $3 \mathrm{x}$ in a month & 3 & 7 & 10 & \\
\hline $4 \mathrm{x}$ in a month & 0 & 7 & 7 & \\
\hline Total & 8 & 22 & 30 & \\
\hline
\end{tabular}


month. In elderly who exercised four times a month, significant insomnia level was not found. This condition is different for elderly who did exercises less than 3 times in a month where moderate insomnia was found. Several studies on exercise duration to maintain sleep quality reported different results. Allessi in Passos et al. ${ }^{11}$ did not found any effect of exercising for 8 weeks but Ferris in Passoss et al. ${ }^{11}$ found improvements after exercising for 3 months. These findings shows the possibility of the involvement of other factors in causing insomnia.

The findings in this study should also be carefully interpreted as the sleep quality assessment conducted was considered to be subjective because data were collected using a

\section{References}

1. Bappenas, BPS, and UNFPA. Proyeksi penduduk Indonesia 2010-2035. BPS. 2013;1(1):1-3.

2. Kim WH, Kim BS, Kim SK, Chang SM, Lee DW, Choet MJ, et al. Prevalence of insomnia and associated factors in a community sample of elderly individuals in South Korea Int Psychogeriatrics. 2013;25(10):1729-37.

3. American Academy of Sleep Medicine. International classification of sleep disorders: diagnostic and coding manual, $2^{\text {nd }}$ ed. American Academy of Sleep Medicine Westchester: IL; 2005.

4. Allah ESA, Abdel-Aziz HR, El-Seoud ARA. Insomnia: prevalence, risk factors, and its effect on quality of life among elderly in Zagazig City, Egypt. J Nursing Education Practice. 2014;4(2):52-69.

5. Tsou MT. Prevalence and risk factors for insomnia in community-dwelling elderly in northern Taiwan. J Clin Gerontol Geriatr. 2013;4(3):75-9.

6. Dewi PA, Ardani IGAI. Angka kejadian serta faktor-faktor yang mempengaruhi gangguan tidur (insomnia) pada lansia di Panti Sosial Tresna Werda Wana Seraya Denpasar Bali Tahun 2013. E J Medika Udayana. 2014;3(10):1-13.

7. Jaussent I, Dauvilliers Y, Ancelin ML, Dartigues JF, Tavernier B, Touchon J, et al. Insomnia symptoms in older adults: associated factors and gender differences. Am J Geriatr Psychiatry. 2011;19(1):88-97.

8. Kim WJ, Joo W, Baek J, Sohn SY, Namkoong K, Youm Y, et al. Factors associated with insomnia among the elderly in a korean rural community. questionnaire that only relies on respondents' ability to recall the facts. Other limitation in the study was that other risk factors contributed to insomnia are not identified. Some elderly who were in non-gymnastics exercise group actually performed another form of exercise such as walking in the morning twice to three times a week and this can create a bias in the analysis of this study because this study only focused on "gymnastics exercise" only.

Hence, a relationship between gymnastics exercise, gymnastics exercise frequency, and insomnia prevalence in elderly is found. It is expected that exercise can be applied as one non-pharmacological treatment alternative in order to improve the quality of life for elderly.

Psychiatry Investig 2017;14(4):400-6.

9. Ogunbode AM, Adebusoye LA, Olowookere 00, Owolabi M, Ogunniyi A. Factors associated with insomnia among elderly patientsattending a geriatric centre in Nigeria. Curr Gerontol Geriatr Res. 2014;2014(2014):1-10.

10. Varrasse M, Li J, Gooneratne N. Exercise and sleep in community-dwelling older adults. Curr Sleep Med Rep. 2015;1(4):232-40.

11. Passos GS, Poyares DLR, Santana MG, Tufik S, Mello MT. Is exercise an alternative treatment for chronic insomnia? Clinics. 2012;67(6):6539.

12. Wang X, Shawn D. Youngstedt. Sleep quality improved following a single session of moderate-intensity aerobic exercise in older women: results from a pilot study. J Sport Health Sci. 2014;3(4):338-42.

13. Sumedi T, Wahyudi, Kuswati A. Pengaruh senam lansia terhadap penurunan skala insomnia pada lansia di panti Wredha Dewanata Cilacap. Soedirman J Nurs. 2010;5(1):13-20.

14. Rahmi U, Somantri B, Alifah NYN. Gambaran pengetahuan lansia mengenai senam lansia di panti sosial Tresna Werdha Budi Pertiwi Kota Bandung 2015. J Pendidikan Keperawatan Indonesia. 2016;2(1):38-43.

15. Yurintika F, Sabrian F, Dewi YI. Pengaruh senam lansia terhadap kualitas tidur pada lansia yang insomnia. JOM. 2015;2(2):111-22.

16. Suastari NMP, Tirtayasa PNB, Aryana IGPS, Kusumawardhani RT. Hubungan antara sikap sleep hygiene dengan derajat Insomnia pada lansia di Poliklinik Geriatri RSUP Sanglah, 
Denpasar. E J Medika Udayana. 2014;3(9):1-18. 17. Manangkot MV, Sukawana IW, Wita IMS. Pengaruh senam lansia terhadap keseimbangan tubuh pada lansia di lingkungan Dajan Bingin Sading. J Keperawatan Community Publishing Nursing. 2016;4(1):24-7. 